\title{
Bedieningspatrone wat die assimilasie van nuwe gelowiges in die gemeente bevorder
}

\author{
Flip Buys \& C.J.H. Venter \\ Dept. Diakoniologie \& Ekklesiologie \\ Potchefstroomse Universiteit vir $\mathrm{CHO}$ \\ POTCHEFSTROOM
}

\begin{abstract}
In this article the problem of assimilating new members into congregational structures is addressed. A further aim of the article is to offer a possible contribution to the role of ministry structures in local churches - simuctures which may promote effective assimilation of new members in such a way that these new members will spontaneously apply and minister their gifts to other people. The object of this ministering involves existing members of the congregation as well as individuals not yet evangelized or assinulated into existing local churches.

In attempting to outline a possible approach to this facet of ministering, the relevant key principles in the New Testament will be summarized. Furthermore, the ministry simuctures of a few Reformed oriented churches in the Uniled States of America will be highlighted as these churches seem to experience a balanced church grow'th. In conclusion, some suggestions regarding a more effective outreach to and ministry of people not yet assimilated imto existing church structures will be given. In this respect Reformed churches in South Africa will have to open up new ways of actively spreading the message of the Gospel.
\end{abstract}

\section{Probleemstelling}

\subsection{Gereformeerde kerke groei nie}

In 1991 het die deputate vir evangeliseringsmedia van die Gerefonneerde Kerke ' $n$ werkskrum in Pretoria gereël waarheen predikante, kerkraadslede, lede van evangelisasie- en/of sendingkommissies en alle belangstellendes uitgenooi is om die omvang en aard van kerke se behoeftes aan hulpmiddels vir die uitdra van die Woord in hulle eie omgewing te bepaal. Een van die ouderlinge wat teenwoordig was, het 'n wydgevoelde probleem so verwoord: "Ons evangelisasiekommissie kry soms die gevoel dat ons 'n lewendige kuiken uitgebroei het, maar dan onder 'n 
dooie hen instop, wanneer ons ' $n$ nuwe gelowige in die gemeente wil laat assimileer."

\subsection{Oorsig oor die omvang van die probleem}

Hierdie ouderling se probleem is deel van ' $n$ veel wyer problematiek van vele tradisioneel reformatoriese kerke: hulle slaag nie daarin om so te evangeliseer dat die gemeente werklik gebalanseerd groei in getalle sowel as in geestelike diepte, ywer en liefde nie.

So byvoorbeeld het Van Eeden (1986:200) in 'n statistiese oorsig aangetoon dat die Nederduitse Gereformeerde Kerk gedurende 1985 slegs 0,027 kerklose mense per gemeente as lidmate van die kerk kon inskakel. Sy konklusie is:

Ten opsigte van die buitekerklike persone behoort die kerk in ' $n$ veel groter mate te slaag as wat tans die geval is. Ook hier is die nodige ondersoek met die oog op effektiewe werkswyses dringend noodsaaklik.

'n Aanduiding van hoe wyd hierdie probleem voorkom, is die feit dat dit selfs enkele jare gelede reeds in die publikasies van gereformeerde ekumeniese liggame aandag geniet het. So byvoorbeeld het Dawid Bosch die probleem aangeraak toe hy in ' $n$ "mission Bulletin" van die Gerefonneerde Ekumeniese Sinode (RES, 1987:10) skryf dat 'n kerk wat nie self 'n stralende manifestasie van die Christelike geloof is nie, nie.' $n$ lewenstyl openbaar wat mense aantrek nie. Sodanige kerk wat tog pogings aanwend om ongelowiges deur middel van cvangeliseringskampanjes aan te trek kan vergelyk word met "a lunatic fanner who carries his harvest into his burning barn".

Die probleem van effektiewe nasorg wat nuwe gelowiges soos nuwe kinders in 'n huisgesin by die gemeente laat inskakel, het ook tydens internasionale sending- en evangelisasiekonferensies aandag geniet. Verskeie voordragte by die Wêreldevangelisasie-konferensie te Lausanne in 1974 het die noodsaak van 'n geestelik volwasse en liefdevolle gemeente vir effektiewe evangelisering beklemtoon (vgl. Douglas, 1975). Tydens ' $n$ opvolgkonferensie, wat deur die Lausanne Committee for World Evangelization in 1980 in Pattaya in Thailand gereël is, is tot ' $n$ eenparige konklusie gekom: die effektiwiteit van sending en evangelisasie hang juis af van die kwaliteit van gemeenteopbou (vgl. Bouw, 1982:12). In Nederland het Bram Krol (1993:3) onlangs aangetoon dat sedert 1980 die Hervormde Kerk 430000 mense verloor het en die Gereformeerde Kerken 100000 . Terwyl die bevolking van Nederland met 2280000 toegeneem het, het die kleiner reformatoriese kerke (d.w.s die HKN en die GKN uitgesluit) met slegs 5000 toegeneem. Indien laasgenoemde kerke slegs dieselfde groeitempo as die bevolkingsgroei sou handhaaf, sou die groei in lidmatetal 335000 moes wees. 
Een van die redes wat aangegee word waarom kerke getalsmatig so min groei, is omdat die gemeentelike strukture te veel na binne gerig is en daarom die assimilasie van nuwe gelowiges bemoeilik

In resente publikasies ten opsigte van gemeenteopbou word al meer beklemtoon dat Skrifgetroue gemeenteopbou daartoe behoort te lei dat 'n gemeente nie net in sy missionêre elan behoort te groei nie, maar juis daarom ook behoort te lei tot bedieningstrukture wat nuwe gelowiges so assimileer dat hulle werklik groei na geloofsvolwassenheid. Hierdie groeiproses behoort te impliseer dat die nuwe gelowige self met hulle eie gawes aktief betrokke sal raak by sowel die intensiewe as die ekstensiewe opbou van die gemeente sowel as die gemeente se diens in die wêreld (vgl. Pauw, 1987:32; Nel, 1987:54; Te Velde, 1992:44; Am, 1993: 24).

\section{Hipotese}

In hierdie artikel word die volgende hipotese gestel:

Die missionêre krag en effektiwiteit van 'n kerk en die vermoë om nuwe gelowiges effektief in die gemeenskap van die gelowiges te assimileer, hang saam met die hele funksionering van die gemeente. Alleen 'n voluit lewende gemeente van Christus wat groei in heiligmaking en geloofsdiepte sal op die lang duur ook kan slaag om effektief in getalle te groei. Aan die ander kant kan 'n gebrek aan groei in getalle 'n simptoom wees van 'n gemeente wat ook geestelik baie oppervlakkig is en nie in die praktyk volgens Bybelse riglyne funksioneer nie.

Bogenoemde hipotese word verder uitgewerk in die lig van Bybelse riglyne en ' $n$ studie van enkele modelle en standpunte van navorsers in resente publikasies.

\section{Nuwe-Testamentiese beginsels}

Hierdie artikel bied nie ruimte vir ' $n$ volledige eksegetiese beredenering en fundering van bepaalde Nuwe-Testamentiese beginsels nie. Bepaalde riglyne word hier as vertrekpunte gestel en slegs op kursoriese wyse eksegeties gefundeer en beredeneer.

\subsection{Gemeenteopbou - teosentriese gerigtheid en doksologiese doel}

Kwalitatiewe sowel as kwantitatiewe opbou en groei van die kerk het 'n doksologiese doel; gevolglik is die kerk nie primêr kerk vir die wêreld nie, maar kerk vir die Here. Die oorkoepelende doel van alle opbou en groei is die eer van die

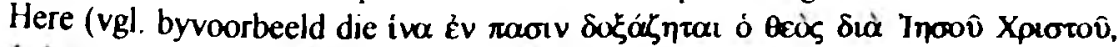

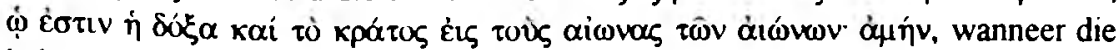
hele doel van die opbou van die gemeente in 1 Petrus $4: 11$ beskryf word). 
Sy eer word egter juis daarin sigbaar dat sy kerk enersyds groei in heiligheid (vgl. byvoorbeeld Ef. 5:27; Op. 15:4 en 1 Pet. 3:18 waar die groei in genade en kennis direk verbind word aan die heerlikheid van die Here) en andersyds groei na volkomenheid in getalle (vgl. byvoorbeeld hoe Paulus in Ef 1:11-14 die gemeente twee maal oproep om die heerlikheid van God ( $\left.\delta \alpha^{\prime} \eta \bar{\zeta} \alpha v i v \hat{)}\right)$ te prys juis omdat hulle die eerstes geword het in die proses waarin God sy volk vergader).

Volgens Matteus 28:18-20 vloei die opdrag om dissipels van al die nasies te mak voort uit die soewereine alomvattende heerskappy van die opgestane Here. Mense word onder die soewereine heerskappy van Jesus gebring deur hulle in sy Naam te doop (wat in die betrokke teks veral die betekenisnuanse het van inlywing in die gemeente van Christus) en hulle ook te leer om alles te onderhou wat $\mathrm{Hy}$ beveel het. Derhalwe is sowel die kwalitatiewe as die kwantitatiewe opbou van die gemeente 'n erkenning van die soewereine koningskap van Christus.

Die teosentriese gerigtheid in die opbou en groei van die kerk sal hom bewaar van 'n horisontalistiese verwêreldliking in sy evangeliserende uitreik na buitestaanders, maar terselfdertyd ook van 'n sieklike selfgesentreerde na-bimnegerigtheid

\subsection{Prediking gerig op kwantitatiewe én kwalitatiewe groei}

Dit het sedert die publikasie van C.H. Dodd se The Apostolic Preaching and Its Developments (1970), taamlik algemeen geword on 'n skerp onderskeid te tref tussen $\kappa \eta \dot{\eta} \varphi \gamma \mu \alpha-$ as synde sendingprediking aan ongelowiges, en $\delta i \delta \alpha \chi \eta-$ as synde lerende prediking wat bedoel is as verdere (veral etiese) onderrig aan

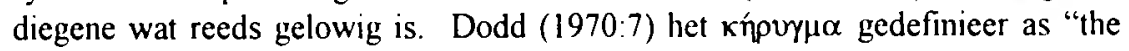
public proclamation of Christianity to the non-Christian world", en Alan Richardson (soos aangehaal deur Watson, 1978:230) het hierdie onderskeid nog skerper deurgetrek deur knpuy $\alpha$ te omskryf as "the telling of news to people who had not heard it before".

Hierdie skerp onderskeiding het die gedagte laat ontstaan dat dit in die kerklike praktyk nodig is om skerp te onderskei tussen opbouende prediking en evan-

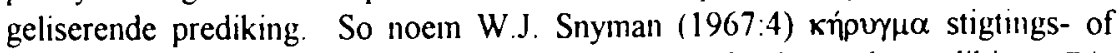
grondleggende prediking en $\delta i \delta \alpha \sigma \kappa \alpha \lambda i \alpha$ stigtelike of opbouende prediking. Die volgende standpunt kom taamlik algemeen voor: Prediking in 'n gevestigde gemeente hoef slegs lerend of opbouend van aard te wees, maar evangeliscrende prediking hoort alleen tuis op die sendingveld of moet slegs tydens spesifieke evangelisasieveldtogte in gemeentes plaasvind. Adams (1982:70) se standpunt is hiervan 'n goeie voorbeeld: "Earlier I noted that preaching is of two sorts: evangelistic and edificational Evangelism in the Scriptures is done 'out there', where the unbelieving are, not primarily in the services of the church". 
In gereformeerde kringe is dikwels in die homiletiek geleer dat knрurpa slegs buite die gemeente op die sendingveld tuishoort. 'n Duidelike eksponent hiervan is Dijk (1955:95) wat in sy homiletiek die volgende beweer:

Immers draagt vanaf het optreden der apostelen de prediking, welke vanwege de kerk geschiedt, een tweevoudig karakter: zij is een kerugma tot degenen, die buiten zijn, dus naar de wereld gekeerd, welk kerugma in de zending en de evangelizatie zijn arbeidsveld vindt, èn een bediening van het Woord Gods, naar binnen, in de gemeente van Jezus Christus, die als kudde van de goede Herder door dit Woord gewijd wordt (beklemtoning deur Dijk).

Die standpunte van Dodd en die praktiese implikasies wat daaruit afgelei is, kan egter nie standhou nie, soos wat R.H. Mounce (1960:60-80) duidelik in sy The Essential Nature of New Testament Preaching, aangetoon het. Firet (1968:66) het ook aangetoon dat die standpunt dat кnি $v \gamma \mu \alpha$ uitsluitlik tot die missionêre taak van die kerk behoort, wel voorgekom het by Kuyper en Sillevis Smit, maar dat Bakker, Wingren, Van Ruler en Miskotte met oortuigende argumentasie aangetoon het dat prediking as $\kappa \eta ́ p v \gamma \mu \alpha$ nie slegs vir buitekerklikes of ongelowiges bedoel was nie. Dijk gee ook geen duidelike Skrifberoep vir sy standpunte in hierdie verband nie. Die vraag kan inderdaad gevra word of hierdie skerp onderskeid tussen evangeliserende en lerende of opbouende prediking wel ' $n$ Nuwe-Testamentiese basis het.

Die implikasie van hierdie standpunte is ook dat daar nie ongelowiges en onbekeerdes in die erediens van die gemeente teenwoordig is nie. Die Nuwe Testament hou egter duidelik daarmee rekening dat daar selfs tussen die gelowiges ook skyngelowiges of hipokriete teenwoordig is (1 Kor. 10:6-12; Heb. 3:12,13; 4:1, 10:26-29; 1 Joh. $2: 19$; Hand. 20:30) en dat nie almal uit Israel werklik Israel is nie (Rom. 9:6).

Verder is dit vanselfsprekend dat daar in die eredienste ook ongelowiges mag binnestap ( 1 Kor. 14:25) en dat 'n gemeente met 'n missionêre hart wat warm klop, moeite sal doen om ook buitestaanders na eredienste toe uit te nooi. Hart (1986:72) omskryf hierdie aspek so: "Die mense wat in die openbare erediens onder die prediking saamkom, is 'altyd 'n mengsel van geestelik volwasse mense, onvolwassenes en onbekeerdes'."

Wanneer alle gegewens nagegaan word, is dit duidelik dat die verkondiging van die evangelie, met die gepaardgaande aandrang tot aanvaarding en die oproep tot bekering, nie slegs aan ongelowiges op die sendingveld gerig word nie, maar ook in die prediking in die gemeentelike samekomste, met die oog op geloofsverdieping en versterking. 
Indien daar in die gewone prediking van die gemeente 'n balans is tussen gerigtheid op die kwalitatiewe opbou en groei van die gemeente, sowel as op kwantitatiewe opbou en groei, sal die gelowiges bewaar word van hoogmoed en Fariseïsme en van oppervlakkige godsdiensbeoefening wat by 'melk' bly staan het.

\subsection{Onderrig en toerusting in die gemeente - intensiewe én ekstensiewe groei}

Volgens die Nuwe Testament is onderrig in 'n sekere sin missionêre arbeid. Vergelyk byvoorbeeld die gebruik van $\delta 1 \delta \not \sigma \kappa \varepsilon ı v$ binne die konteks van Handelinge $5: 28 ; 20: 20,21$. Van Swigchem (1955:156) vat hierdie betekenisnuanse saam

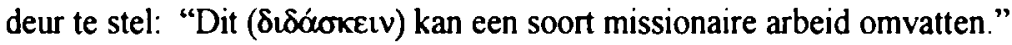

In 'n ander sin impliseer $\delta$ io algehele gehoorsaamheid aan die Here. By hierdie gehoorsaamheid is ook betrokkenheid by missionêre arbeid inbegrepe (vgl. byvoorbeeld die struktuur van die opdrag in Matt. 28:19 waar die dissipels juis geleer moet word om ook van ander dissipels te maak). De Ridder (1971:193) het hierdie opdrag só verwoord: "In being obedient to what He has commanded them, they become the agents to pass on that will and commandment to still others."

Onderrig in die gemeente het ook volgens die Nuwe Testament baie duidelik die karakter van onderrig deur voorbeeld. Onderrig kan alleen geskied in die konteks van intieme gemeenskapsbeoefening van gelowiges met inekaar waar hulle uit mekaar se lewenswyse en optrede in 'n verskeidenheid van situasies kan leer hoe om as kinders van God in die wêreld te leef tot sy eer.

\subsection{Pastoraat en missionêre arbeid}

Pastoraat wat toerus vir missionêre arbeid bestendig in die meeste gevalle ook die vrug van die kwantitatiewe groei. Volgens die Nuwe Testament moet die pastoraat in die gemeente dan ook voortdurend 'n missionêre blikpunt behou. Die pastorale aanwysings in 1 Petrus 3:1-6,1 Korintiërs 7:12-17 en Titus 2:3-5 hou duidelik rekening met missionêre aspekte.

Verder moet gelowiges in elke aspek van hulle lewe in gedagte hou dat die oe van die buitestaanders op hulle gerig is. Daarom moet hulle so lewe dat hulle met hulle totale lewenswandel die woordgetuienis wat hulle bring, nie ontkrag nie, maar versterk. Dit gaan in pastorale versorging nie maar net daarom dat mense in hulle nood op ' $n$ empaties bewoe manier begelei word met die troos van die evangelie nie, maar dat hulle in die pastoraat ook bekwaam gemaak moet word om missionêr effektief te kan wees. Daarom het Bolkestein (1964:122) gelyk as hy beweer: "Dat zielzorg geen introvert karakter draagt, maar mee opgenomen is in de dienst van de gemeente in de wereld spreekt vanzelf. De 'toerusting' van 
de gemeente, die in zielzorg word beoogd, betreft mede deze dienst." (Bolkestein maak hierdie stelling nadat hy die pastoraat volgens Nuwe-Testamentiese riglyne indringend ondersoek het.)

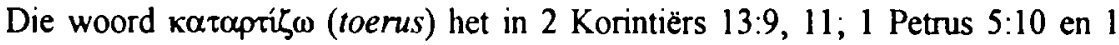
Tessalonisense 3:10 die betekenisnuanse van om aan te vul wat nog ontbreek. Die implikasie daarvan is dat die pastoraat aan nuwe gelowiges dringend noodsaaklik is - om hulle te bestendig in die nuwe lewe in Christus waarby hulle langs die weg van geloof en bekering ingelyf is.

Uit 1 Korintiërs 5:9-13, gelees binne die konteks van 1 Korintièrs 4 (veral vers 7), is dit duidelik dat die gelowiges nooit met ' $n$ hooghartige houding met buitestaanders behoort om te gaan nie. Daar behoort altyd in missionêre arbeid met ' $n$ bewoë pastorale grondhouding na buitestaanders uitgereik te word. Om dit te kan doen, moet die gelowiges self eers baie diep deur die genade van God getref word. Paulus se vermaning moet belydenis en leefwyse word: "Wat het ons wat ons nie ontvang het nie? As julle dit alles ontvang het, wat roem julle dan asof julle dit nie ontvang het nie" (1 Kor. 4:7).

Met so 'n gesindheid sal die gelowiges se missionêre arbeid inderdaad die karakter dra van "one beggar telling another where to find bread" soos D.T. Niles dit gestel het (aangehaal deur Peters, 1975:581). Dan kan die gemeente werklik "die reddingsdade verkondig van Hom wat hulle uit die duisternis geroep het tot sy wonderbare lig" (1 Pet. 2:9, 10) en word hulle soos Paulus "deur die liefde van Christus gedring" ( 2 Kor. 5:14). Ook sal hul poog om ander te probeer oortuig en sal hulle self die liefde van Cluristus ervaar as "een even dwingende als heerlijke macht, die hem zozeer beheerst en vervult, dat hij zijn leven wel ten dienste van andere moet stellen" (Van Swigchem, 1955:223).

\subsection{Die kwalitatiewe opbou en evangeliserende impak van die ere- diens}

Volgens 1 Korintiers 14:21-25 is dit duidelik dat die samekoms van die gemeente nie net gedien het tot die kwalitatiewe opbou van die gelowiges nie, maar ook tot die kwantitatiewe opbou van die gemeente. Kwantitatiewe opbou vind plaas wanneer ongelowiges wat deur die aanbiddende en lofprysende gemeente getrek word, tot bekering kom en deel van die gemeente word. Dit is ook duidelik dat

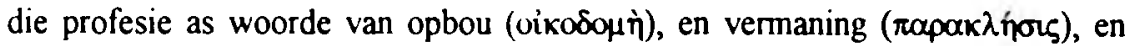
bemoediging ( $\pi \alpha p \alpha 0 v$ uía) verwys na die totale liturgiese uiting van die gemeente in die erediens. Dit kan selfs die viering van die Nagmaal insluit, want dit ver-

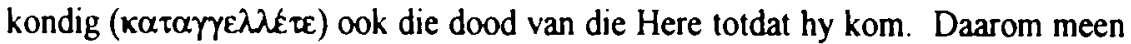
Bieder (1964:12) dat die kerk in sy aanbidding en in sy totale lewenswyse iets van 'n sakrament vir die wêreld moet wees. Soos wat die sakramente vir die ge- 
lowiges 'n Schauplatz der Götlichen Treue is, so moet die kerk juis ook dit vir die wêreld wees.

Von Allmen (1965:79) sê in hierdie verband van die erediens:

... by the mere fact of its celebration and because it is a power radiating joy, peace, freedom, order and love, it becomes an evangelizing force, and hence something which impinges upon the surrounding world. Worship provides a sign which is for the world a challenge and promise. Thus it has a power of evangelization hardly guessed at. That is why it is so important that the Christian cult should be celebrated with a maximum of theological urgency and spiritual fervor.

Die feit dat die erediens 'n evangeliserende impak behoort te hê beteken nie dat die doel van die aanbidding in die eerste plek gerig is op die bekering van ongelowiges nie: ware aanbidding is in die eerste plek op God self gerig. Maar, juis waar Hy in sy heerlikheid en majesteit opreg geloof, geprys en aanbid word, het dit tegelyk ' $n$ invloed op ongelowiges wat teenwoordig is. Die integriteit van die erediens mag nie vernietig word deur daarvan ' $n$ blote evangelisasieveldtog te maak nie.

Die eenheid tussen die kwalitatiewe en kwantitatiewe opbou van die gemeente lê in die Christosentriese, teosentriese karakter van die erediens. Terwyl die teenwoordigheid van Christus deur sy Gees in Woordverkondiging en sakrament, belydenis, gebed en sang gevier word, word sy versoeningsdood terselfdertyd verkondig:

We declare in evangelism that one day everything will stand under his feet (Ephesians 1:22; 1 Corinthians 15:25-28; Hebrews 2:7-8), and we fall at these same feet in worship ( 1 Corinthians 14:24-25). The vision of Jesus lifted up is the same in both (Christian Reformed Home Missions, 1984 : 11).

\subsection{Diakonia en koinonia wat kwalitatief en kwantitatief opbou}

Volgens die Nuwe Testament kan kwantitatiewe en kwalitatiewe opbou en groei alleen plaasvind waar daar in die gemeente 'n hegte liefdesgemeenskap tussen

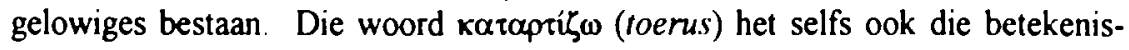
nuanse van saamsnoer tot ' $n$ eenheid.

Die gelowiges se eenheid met Christus lê 'n dure plig op hulle om ook in eenheid en liefdesgemeenskap met mekaar te lewe (1 Kor. 1:10-17; Ef. 4:1-7), want omdat gelowiges hulleself aan Christus oorgegee het en in God se lig wandel, het hulle gemeenskap met mekaar (1 Joh. 1:7) en gee hulle hulleself ook onvoorwaardelik aan mekaar juis met die oog op die verdere uitdra van die evangelie (2 Kor. 8:4,5). "To embrace the gospel then is to enter into community" (Banks, 
1980:33). Juis met dié doel voor oë om effektief missionêre instrument van God te kan wees, moet gelowiges mekaar met selfverloënende liefde liefhê (Joh. $13: 34,35 ; 17: 21,23 ;$ Fil. 1:27), want dan word God verheerlik!

Die eerste gemeente in Jerusalem se onderlinge liefde, eenheid en gemeenskap het juis missionêre trekkrag ten opsigte van die buitestaanders gehad en het 'n belangrike bydrae gelewer tot die getallegroei van die kerk (Hand. 2:46, 47; 5:13, $14,6: 1,7)$.

Hierdie liefdesdiens mag egter volgens Jesus se uitdruklike bevel nie net gerig wees op medegelowiges nie, want een van die kenmerke van egte Christelike liefdesdiens is dat dit soos Christus se eie liefde onvoorwaardelik is en ook betoon sal word aan diegene van wie nie ook liefde ontvang word nie (Matt. 5:46, 47; Luk. 6:32, 33).

Deur konkrete dade van liefdesdiens is die gelowiges besig met daadverkondiging van die evangelie (Matt. 5:16; I Pet. 2:12). Waar die kerk dienend in die wêreld teenwoordig is, word die koms van die koninkryk sigbaar.

\subsection{Strukture waarbinne koinonia en diakonia kwalitatief en kwantitatief opbou}

Die Nuwe Testament gee weinig voorskrifte oor organisatoriese strukture waarbimne koinonia en diakonia moet plaasvind. Organisatoriese strukture in die vroeë kerk is wel deur sekere riglyne bepaal, maar die praktiese vormgewing daarvan is meer pragmaties as prinsipieel bepaal. Gelowiges is beveel om mekaar lief te hê, om met mekaar gemeenskap te beoefen en mekaar te ondersteun in hulle getuienistaak in die wêreld, en dit alles te doen onder leiding van en toerusting deur die voorgangers. Die konkrete vormgewing van strukture waarbinne dit geskied, is aan hulle oorgelaat om in die lig van praktiese omstandighede en onder leiding van die Heilige Gees uit te werk. Eckert (1979:22) formuleer dit so:

The mentality of the earliest Christians did not spring from their desire to found a new religion which would make its presence felt in this world for a long time as an institution endowed with a growing bureaucracy and building a lot of churches. They rather saw themselves as an eschatalogical movement which expected final salvation to come, not from the traditional Jewish faith nor from the secular reforms in this world, but from the Christ who would come again in power and glory (see I Thess 1:9f; 1 Cor 7:2931, 16:22: Mrk 13).

Daar bestaan egter oorvloedige getuienis dat die hegte gemeenskapsbelewing veral in klein huisgemeentes gedy het. Vogler (1982:786-794) kan - met deeglike bewysvoering - oor die eerste gemeentes in Judea en Galilea beweer: "... dürfte unbestritten sein, dass diese Gemeinden Hausgemeinden waren Denn zu 
dieser Zeit gab es noch keine kirchlichen Räume oder Gebäude". Dit is inderdaad so dat daar nie getuienis bestaan van enige kerkgeboue voor die derde eeu na Christus nie (Banks, 1980:41).

Die huisgemeentes (Rom. 16:5; 1 Kor. 16:19; Kol. 4:15; Fil. 2) het ruimte gebied vir intieme gemeenskapsbelewing maar het ook "eine intensive Ausbreitung des Evangeliums betrieben und diese Ausbreitung hat sich nicht nur auf Jüden, sondern auch auf Heiden erstreckt" (Vogler, 1982:787).

Merkwaardig is die vertelling oor die eerste Christelike gemeente in Jerusalem: Hulle het in die tempel en in die Pilaargang van Salomo vergader (Hand 3:11; $5: 12$ ), maar het ook $\kappa \alpha \tau$ ' oikov (Hand. 2:46) byeengekom - 'n omskrywing wat ook met huisgewyse vertaal kan word. In die samekomste het gebed klaarblyklik 'n vername plek beklee (Hand. 12:12), maar ook die leer van die apostels, die onderlinge gemeenskap en die gesamentlike maaltye (Hand. 2:42-47).

Hoe strukture ook al ingeklee word, moet dit so gedoen word dat sowel die impak van die groot samekoms in die erediens as die intieme meelewing van kleingroepbediening gestimuleer word.

\subsection{Die funksionering van charismata en voorgangers}

Volgens die Nuwe Testament is dit baie duidelik dat elke gelowige gawes ontvang wat gebruik moet word in bedieninge tot opbou van die gemeente. Dit is merkwaardig hoe dikwels die woorde almal en elkeen voorkom in al die teksgedeeltes wat handel oor die gawes van die Heilige Gees (Rom. 12:3; 1 Kor. 12: 11 en 28-31; Ef. 4:7 en 1 Pet. 4:10). Waar elke gelowige sy of haar gawes gebruik, word die gemeente kwalitatief sowel as kwantitatief opgebou.

Gawes aan elke gelowige beteken egter nie dat daar nie ook bepaalde gelowiges is wat met hulle gawes as voorgangers moet funksioneer nie. Die voorgangers se taak is egter tweërlei van aard: om die dienswerk van al die gelowiges te koördineer en om gelowiges toe te rus vir hulle dienswerk (Ef. 4:7-16 en Kol. 2:20; vgl. ook Versteeg, 1985:27; Roberts, 1983:124 en Buys, 1989:109 en 245 e.v.).

Die toerusting deur voorgangers moet deur woorde maar ook deur hulle voorbeeld gegee word (1 Pet. 5:3; 1 Kor $4: 16 ; 11: 1$; Fil. 3:17).

Die implikasie is dat die voorgangers en die ander gelowiges in die gemeente dieselfde basiese funksies vervul in die opbou van die gemeente. Voorgangers se arbeid is slegs 'n toespitsing van dit wat alle gelowiges doen (Roberts, 1976:15). Voorgangers wat nie daarin slaag om gelowiges onder hulle sorg te motiveer en te begelei tot dienswerk volgens hulle eie gawes nie, vervul nie werklik hulle roeping nie. 


\section{9 'n Grociende kerk is 'n biddende kerk}

Die primêre instrument wat die Heilige Gees gebruik om kwalitatiewe sowel as kwantitatiewe groei in die gemeente van Christus teweeg te bring, is die bediening van die evangelie van Jesus Christus (1 Pet. 1:23, Rom. 10:17; H.K. vr. 65).

God die Heilige Gees is soewerein en skenk nie outomaties groei oral en altyd waar die evangelie bedien word nie. Die sogenaamde per verbo standpunt van die Lutherane beteken dat die Heilige Gees outomaties werk waar die Woord verkondig word. Die cum verho standpunt van Calviniste bely dat die Heilige Gees saam met, dit wil sê in, onder en deur die bediening van die evangelie in mense se harte werk slegs wanneer dit Hom behaag.

Die Heilige Gees laat Hom egter beweeg deur die gebede van God se kinders - 'n onverstaanbare en onnaspeurlike geheim. Die ewige God skakel ons gebede in, in die proses waarnee $\mathrm{Hy}$ die getalle van die uitverkorenes laat vol word en hulle aan die beeld van Christus gelyk maak. God gee egter "sy genade en sy Heilige Gees slegs aan diegene wat Hom met hartlike sugte sonder ophou daarom bid en daarvoor dank" (H.K. Son. 45). Dit was Jesus Christus se bedoeling dat gebed 'n groot krag moes wees waardeur die kerk medewerkers word in die koms van die koninkryk.

Volgens die Bybel moet daar met betrekking tot groei onder andere voortdurend gebid word:

* dat God die nodige gewillige medewerkers vir georganiseerde en gestruktureerde evangeliseringswerk sal gee (Matt. 9:38);

* dat die mense wat die evangelie hoor se harte deur die Heilige Gees oopgemaak sal word (Kol. 4:2);

* dat die Heilige Gees aan dié wat die praatwerk doen die nodige vrymoedigheid, insig en oortuigingskrag sal gee (Hand 4:29; Ef. 6:19);

* vir nuwe gelowiges se geloofsgroei en bewaring teen die aanvalle van die duiwel (Fil. 1:9-10);

* vir enige spesifieke behoeftes in die werk van die Here wat tot sy eer is en sy naam wil verheerlik (Fil 4:6);

* om medewerkers te wces in die verkondiging van die evangelie (Rom 15:30).

Michael Green wat indringende navorsing gedoen het oor die geheim van groei in die Vroeë Kerk in die ecrste drie eeue na Christus en verskeie publikasies daaroor die lig laat sien het, formuleer die belang van gebed as prioriteit in gemeenteopbou soos volg: 
Do you know a church where the priority is prayer? Prayer in individual lives, in prayer cells, in half-nights of prayer? If you do, I can tell you one thing about that church. It will be evangelizing. In some way or other the good news of Jesus will be going out. Prayer is a priority in evangelism. Without it lives do not get changed, however great the activism and however enthusiastic the proclamation. Most churches do not see church growth because they do not want it enough to pray for it (Green, 1979:27).

\section{Enkele modelle krities onder die loep}

In die lig van die Nuwe-Testamentiese beginsels wat tot dusver aangestip is, word enkele modelle nou krities onder die loep geneem. Die modelle wat nader beskryf word, funksioneer binne sekere kerkgroeperinge en die beskrywing van hierdie modelle berus hoofsaaklik op empiriese waarneming en evaluering.

\subsection{Die Redeemer Presbyterian Church in Manhattan New York}

\subsubsection{Ontstaan}

Hierdie gemeente, in die hart van Manhattan in New York, het ' $n$ raps meer as vier jaar gelede ontstaan uit vyf huisgesinne wat in 'n Bybelstudiegroep saamgekom het. Sedert daar in September 1991 met eredienste begin is, het die bywoningsyfer elke 12-14 maande verdubbel sodat daar in 1993 reeds 1025 mense die vier verskillende eredienste op 'n Sondag bywoon.

\subsubsection{Belydenis en geloofsoortuigings}

Keller (1992:2) skryf onder andere in 'n artikel:

An unspoken assumption is: 'If you're pure and truly Reformed, you'll stay small, and if you've grown it's because you've compromised Reformed distinctives in doctrine and practice'. The surprise is the 'reverent worship' and the high visibility of the 'doctrines of grace' that a worshipper encounters at Redeemer. The first three worship services include a confession of sin, responsive reading of Scripture, a portion of the Heidelberg Catechism, three traditional hymns and classical music for preludes. Officer candidates and many other interested lay people went through several months of studying the Westminster Confession. Reformed material, doctrines and assumptions are both explicit and implicit in adult Sunday School, small group leader training, couples fellowships, premarital seminars, counseling, Women's Discipleship Network and the ex-gay support group.

Op die eerste bladsy van die gemeenteblaadjie (bulletin) wat elke Sondag uitgedeel word, word gewoonlik gebruik gemaak van aanhalings van Calvyn, 
Thomas Brooks, Samuel Rutherford, Augustinus, J.I. Packer, John Owen, Martin Luther, Charles Spurgeon en ander bekende teoloè.

In 'n inligtingstuk wat met alle nuwe lidnate behandel word, word eksplisiet verduidelik hoe hierdie kerk anders wil wees as charismatiese, Rooms-Katolieke en modeme liberale kerke. Die Redeemer Presbyterian Church onderskei hom van genoemde kerke deur vas te hou aan die ekumeniese belydenisskrifte, die gereformeerde standpunt oor die sakramente en die unieke gesag van die Skrif, die bonatuurlike aard van die Christendom, die onfeilbaarheid van die Skrif, die Godheid van Christus, die maagdelike geboorte, die liggaamlike opstanding en sigbare wederkoms van Christus. Daar word ook pertinent uitgespel dat die gemeente sy gereformeerde karakter daarin beleef en bely dat "salvation is totally by grace and gift, that God is sovereign over all of life" (Keller, 1992:2).

\subsubsection{Bedieningsmissie en -visie, doelwitte en strategieẽ}

In die inligtingstuk vir nuwe lidmate word uitgespel dat die gemeente hom ten doel stel "to bring the resources of the historic Cliristian faith to bear on the city until we make a visible difference in the quality of its life, spiritually, socially, economically, culturally" (Redeemer Presbyterian Church, 1993:2).

Die eerste doelwit is on die aantal Clristene in Manhattan te sien vermeerder, deurdat duisende sal toetree tot 'n persoonlike en transformerende verhouding met God die Vader deur Jesus Christus.

Die strategiee hiervoor is om 'n verskeidenheid van groot worship celebrations te hê wat sowel gelowiges opbou, asook geestelik skeptiese mense en soekende belangstellendes en ongelowiges sal konfronteer en help. Verder word daarop klem gelê dat elke lidmaat ongelowige vriende met dienende liefde en voorbidding vir die koninkryk van God moet wen. 'n Visie wat uitgespel word, is dat $5 \%-10 \%$ van die inwoners van die stad teen die einde van die dekade 'n Christelike lewenstyl sal hê en mense dan elke dag die grens na geloof in Christus sal oorsteek.

Verdere doelwitte wat gestel word, is om kleingroepbediening so uit te bou dat enige lidmaat binne vyf minute se stapafstand van sy huis af by ' $n$ groep se samekomste kan inskakel. Daar word beoog om $75 \%-80 \%$ van diegene wat eredienste bywoon by sulke kleingroepe in te skakel sodat daar binne ses jaar 200 groepe sal wees. Die uitgesproke bedieningsfilosofie in hierdie verband is: 'a traditional church has small groups, but our church is small groups'.

Dan word ook nou reeds beplan om binne die volgende sewe jaar vyftien nuwe gemeentes te laat afstig en dat daar binne twintig jaar 100 nuwe gemeentes in die groter New York-gebied sal ontstaan. 
Nog ' $n$ doelwit is om met die Christelike waarhede verskillende terreine van die stadslewe binne te dring - terreine soos kuns, handel en nywerheid, regeringsinstansies, politieke organisasies, onderwysinstansies, plaaslike regering en wetstoepassingsinstansies. Die strategie daarvoor is om Christelike waarhede te verkondig in klubs en organisasies deur etensuurbesprekingsgroepe, kunsuitvoerings wat die boodskap dra, en deur verteenwoordiging van Christene op allerlei rade te verkry. Die bedoeling is nie om die samelewing te verkerklik nie, maar om gelowiges aan te moedig om hulle Christelike getuienis in elke samelewingsverband uit te dra.

Verder word beoog om die liefdesdiensprojekte wat reeds tot stand gekom het, uit te bou deur noodleniging, ontwikkelingshulpprojekte en pastorale beradingsdienste vir mense wie se lewens stukkend en verskeurd is. Deur byvoorbeeld jong ongehude moeders te help om hulle babas na geboorte te kan versorg en self weer met die lewe voort te gaan, wil die gemeente nie in die eerste plek 'n anti-abortion kerk wees nie, maar 'n pro life-gemeente

Omdat ongeveer 50 persent van die lidmate enkellopende vrouens is, is daar ook 'n hele span unordained deaconesses wat aan hierdie projekte leiding gee.

\subsubsection{Evaluering}

'n Besoeker word werklik deur die bediening van en gecsdrif in hierdie gemeente besiel. Dit is duidelik 'n gemeente wat wil vashou aan dic onvervalste Bybelse waarhede soos dit in die tradisionele gereformeerde belydenis bely word. Tegelyk word gepoog om hierdie waarhede op 'n grootse en verbeeldingryke manier relevant te laat wees om die lig van die evangelie in die middestad van Manhattan te laat skyn.

By ' $n$ waarnemer van buite ontstaan egter die indruk dat die hele bediening so professioneel en op so 'n hoë intellektuele niveau ingeklee word dat dit ietwat gekunsteld oorkom. Al is dit so dat die teikengroep vir die gemeente se bediening die yuppies-meerderheid van daardie omgewing is, ontstaan die vraag tog of minder gegoede en ontwikkelde mense in so ' $n$ gemeente wel 'n tuiste sal vind.

\subsection{Die New Life Presbyterian Church in Jenkintown, Philadelphia}

\subsubsection{Ontstaan}

Hierdie gemeente het in 1972 ook ontstaan uit 'n Bybelstudiegroep wat Jack Miller, predikant en professor van die Orthodox Presbyterian Church aan die Westminster Theological Seminary in Philadelphia, saam met sy eggenote in sy huis begin het (New Life Presbyterian Church, 1992:1). Ongeveer twaalf gelo- 
wiges het hulle gedring gevoel om behoeflige mense te help om vergifnis en herstel in Christus te vind en het met die oog daarop 'n nuwe gemeente begin.

Oor die afgelope 20 jaar het daar toenemende groei plaasgevind en 'n aantal nuwe gemeentes is reeds afgestig. Op die oomblik het die gemeente weer ongeveer 800 lidmate wat deur vyf predikante bedien word. Een predikant word afgesonder vir plaaslike evangelisasie, een vir junior jeugwerk, een vir senior jeugwerk, een vir die stimulering en uitbou van kleingroepbediening en een wat naas sy funksie van voorsitter van die kerkraad en die bantering van $60 \%$ van die preekbeurte, veral moeilike pastorale probleme hanteer.

Daar was ook voortdurend ' $n$ intense belangstelling in wêreldsending sodat die gemeente van die laat sewentigjare sendingspanne (vir korter en langer periodes) uitgestuur het na Uganda, Ierland, Kenia, Spanje, Equador, Amsterdam en later ook Rusland en die Oosbloklande. Die gesinne wat hulleself voltyds in die buiteland as sendelinge gaan vestig het, word ten volle of gedeeltelik deur die gemeente onderhou. Jack Miller, die eerste predikant, is tans self een van die gemeente se sendelinge in Spanje.

\subsubsection{Belydenis en geloofsoortuigings}

In een van Jack Miller se vele publikasies met die titel Evangelism and Your Church (1980) skryf Jay Adams in die voorwoord: "Jack Miller is a Calvinist; that fact becomes clear from page one. He is concerned about the lack of evangelism by Bible believing Reformed Churches of which he has been part" (Miller, 1980:ix). In die eerste hoofstuk van hierdie publikasie betoog Miller dan (met breedvoerige aanhalings uit die geskrifte van Calvyn en ander reformatoriese teoloe sowel as met verwysings na die kerkgeskiedenis), dat die meeste hedendaagse gereformeerde kerke hulle reformatoriese erfenis verloèn het. Hierdie verloëning trek daarin saam dat die uitdra van die evangelie van redding deur Christus, uit genade alleen, nie meer die hoogste prioriteit in die bediening van die kerk is nie, maar gedevalueer is tot 'n bysaak. Die volgende aanhaling tipeer sy betoog:

... somewhere in the years between Calvin's century and ours, our working theology has become abbreviated in a way that would have dismayed such a pioneer in missions. Our emphasis on the wonderful doctrines of grace has somehow come to mask and perhaps (in our own minds) even justify a deep-seated indifference to the lost. Evangelism, God's first priority for His Word and His church, has become a peripheral activity in the lives of many local congregations (Miller, 1980:5).

Die liefde vir en beklemtoning van groot gereformeerde waarhede in die alledaagse gang van die gemeentelike lewe en veral die relevansie daarvan in die uitoefening van die kerk se evangeliseringsroeping, het deur die jare steeds gebly. 
Toe een van die skrywers van hierdie artikel op Sondag 9 Mei 1993 in die gemeente ' $n$ erediens bygewoon het, het Angelo Juliano, die evangelisasiepredikant die oggend in die gemeente voorgegaan in die prediking met 'n preek oor "The sovereignty of God". Daarin het hy die troos van die uitverkiesing en die majesteit van God se raadsplan in eg reformatoriese taal verduidelik.

\subsubsection{Bedieningsmissie en -visie, doelwitte en strategieë}

In hierdie gemeente word die gemeente al vir jare geleer dat die doel van hulle hele bestaan en voortbestaan met die volgende missie saamgevat kan word: 'To know Christ and to make him known'. Hierdie missie is nie net met groot letters op die mure van die kerk en kennisgewingborde aangebring nie, maar word ook op alle kerklike stukke (nuusbriewe, offisiële dokumente en progamme) afgedruk en telkens in die beplanning van al die gemeentelike aktiwiteite in ag geneem.

Daar is vier tipes gereelde samekomste wat klem ontvang. Die vernaamste is gereelde samekomste vir gebed en voorbidding twee maal per week, naamlik elke Donderdag van 7:00 soggens af tot 10:30 (waar lidmate kom en gaan en deelneem soos wat hulle dit by hulle dagprogram kan inpas) en elke Sondagmiddag om 15:30 vir diegene wat nie Donderdagoggende kan kom nie.

Dan is daar elke Sondagoggend eredienste om 9:00 en 10:30 waar die klem val op plegtige dog hartlike en feestelike aanbidding en deeglike Woordverkondiging. Die doel en inhoud van eredienste word so geformuleer:

- Shekinah Glory manifested at each worship assembly.

- Joy in the person and work of Christ.

- Passionate, dignified, solemn, enthusiastic praise.

- Powerful corporate prayer.

- Christ centered, expository, relevant preaching

- Sacraments faithfully administered.

- Testimonies planned and unplanned.

- Strong musical presence in a multiplicity of styles.

- Giving of finances is generous and cheerful (New Life Presbyterian Church, 1993:4).

In die gemeente word ook groot klem op kleingroepbediening gelê en een predikant word uitsluitlik daarvoor afgesonder. Hy volg 'n deeglike opleidingsprogram vir kleingroepleiers en hou gereelde kontak met kleingroepleiers, waar probleme en die uitbou van kleingroepe bespreek word. 
Elke Vrydagaand is daar 'n omvangryke aksie van jeugbediening waar ongeveer 200 jongmense van verskillende ouderdomsgroepe in spanne onder leiding van gemeentelede vergader vir Skrifstudie, speletjies en om dienswerkprojekte in die gemeente en gemeenskap te bespreek.

In die gemeente word ook 'n hele toerustingsprogram van voorgangers geïmplementeer.

\subsubsection{Evaluering}

Wat uniek is aan New Life Presbyterian Church is sy wêreldwye missionêre visie. Die evangelie word plaaslik sowel as in ander lande op 'n verbeeldingryke manier uitgedra. Die eredienste getuig van deurleefde meelewing, en die gebedsamekomste van ' $n$ diep besef van hulle afhanklikheid van die genadekrag van die Heilige Gees in die opbou van die gemeente. Die klem op en styl van kleingroepbediening dra by tot ' $n$ gees van openhartigheid en hartlikheid in die hele gemeente.

Dit skyn tog of die waarheid van die gawes van die Heilige Gees aan elke gelowige in die praktyk van die gemeentelike lewe nog nie ten volle tot sy reg kom nie en die ampsdaers nog te veel die gemeente se aktiwiteite oorheers. In 'n besprekingsdokument wat tans deur die kerkraad oorweeg word en waarin deeglike toekomsbeplanning gedoen word, word inderdaad ook aan die hand gedoen dat die identifisering en implementering van gelowiges se gawes in die totale bediening van die gemeente deegliker aandag behoort te geniet (New Life Presbyterian Church, 1993:8).

\subsection{Die Willow Creek Community Church in Chicago}

\subsubsection{Ontstaan}

In 1975 het 'n groep jong mense onder leiding van Bill Hybels die visie gekry om 'n nuwe gemeente te stig (Stewart, 1991:25-45) wat hom primêr ten doel stel om buitekerklikes in Chicago op nuwe en innoverende maniere te bereik.

Spoedig is in die bediening van die evangelie onderskeid getref tussen seeker services ('n tipe evangelisasie-samekomste) op Saterdagaande en Sondagoggende wat primêr gerig is op buitekerklikes, en worship services op Woensdag en Donderdagaande (eredienste wat gerig is op die geloofsopbou van die gemeentelede).

Daar is vandag ongeveer 6000 lidmate en gemiddeld 15000 mense woon die evangelisasiesamekomste op Saterdagaande en Sondagoggende by. 
Drie maal per jaar word 'n leadership seminar in die gemeente aangebied waar die bedieningsdoelwitte en -strategieë en allerlei praktiese bedieningsmetodes by Willow Creek Community Church aan besoekers meegedeel word. By so 'n seminaar wat een van die skrywers van hierdie artikel bygewoon het, was ongeveer 1500 besoekers teenwoordig - besoekers uit verskillende kerke en dele van die Verenigde State van Amerika, Kanada, Engeland, Australië, Nieu-Seeland, SuidAfrika, Duitsland en Switserland.

\subsubsection{Belydenis en geloofsoortuigings}

Bill Hybels het self opgegroei in die Christian Reformed Church en 'n deel van sy opleiding by Dordt College en Trinity College ondergaan. Hy het egter skerp kritiek teen (volgens hom) die gebrek aan evangeliese bewoënheid en egte Christelike liefde en ook teen die formalistiese verstarring in hierdie kerk. Die Willow Creek Community Church is 'n interdenominasionele kerk wat wel as 'n kerk in die Calvinistiese tradisie beskou word (Towns, 1990:258). Hybels self getuig dat naas sy studie van die boek Handelinge, veral die geskrifte van Robert Schuller hom baie geïnspireer het in sy aanvanklike visie om 'n gemeente te stig wat radikaal anders is (Stewart, 1991:35).

Benewens ' $n$ verklaring dat die gemeente die historiese ekumeniese belydenisskrifte aanvaar, is ook 'n statement of faith saamgestel wat die volgende bely: die onfeilbare gesag van die Bybel as die Woord van God, die Drie-eenheid van God, verlossing uit genade alleen, die Godheid van Christus en die Heilige Gees en die werk van die Heilige Gees in wedergeboorte en heiligmaking, die wederkoms van Christus, die liggaamlike opstanding uit die dood en die ewige oordeel van God. Wat die kerk betref, word die universele kerk, bestaande uit alle ware gelowiges bely, maar ook dat dit elke gelowige se plig is om hom/haar by 'n plaaslike gemeente te voeg en daar sy/haar gawes tot opbou van die gemeente aan te wend. Daar word slegs gepraat van die plig om te deel in die sakramente van die Doop en die Nagmaal en ook dat slegs mense wat as gelowiges gedoop is, aansoek mag doen om lidmate van die gemeente te word.

\subsubsection{Bedieningsmissie en -visie, doelwitte en strategieë}

In a Statement of purpose (Stewart 1991:5) word uitgespel dat die gemeente bestaan "for the four-fold purpose of exaltation, edification, evangelism and social action".

Onder exaltation word verstaan dat die kerk aan die gelowiges die geleentheid wil bied om God te aanbid en te verheerlik. Onder edification word verstaan dat die gelowiges gehelp moet word om 'n fondament van Bybelse insigte te verwerf, persoonlike godsvrug en gemeenskap met God aan te leer en hulle eie gawes van die Gees te identifiseer ten einde deelnemende lede van die liggaam van Christus 
te kan wees. Onder evangelism word verstaan dat die gemeente wil bestaan met die doel om mense te bereik wat die ewigheid sonder Christus tegemoet gaan. Alle gemeentelede word aangemoedig om buitekerklikes op te soek en geleenthede te benut om Christus se liefde met hulle te deel. Onder social action word verstaan dat die gemeente as 'n gewete vir die wêreld wil funksioneer deur die liefde en geregtigheid van God met woorde en dade te demonstreer.

Die bedieningsfilosofie word in vier punte uitgestippel:

* Al het alle gelowiges nie die gawe van evangelisering nie, het elkeen tog die plig om ' $n$ getuie van Christus te wees.

* Die behoeftes van die seeker verskil van dié van iemand wat reeds 'n gelowige lid van die gemeente is. Hieronder word verstaan dat dit onmoontlik is om in dieselfde erediens ingestel te wees op intensiewe sowel as op ekstensiewe groei en opbou.

* Gelowiges moet respek hê vir elke indiwidu se proses om tot geloof en geloofsbeslissing te kom en die weg van groei tot geloofsvolwassenheid. Daar mag geen druk op mense uitgeoefen word om tot bekering te kom nie en daar moet onthou word dat geloofsbeslissings nie altyd op 'n spesifieke tyd en datum gebeur nie. Ook moet onthou word dat bekering nie 'n enkele moment is nie, maar 'n lewenslange proses.

* Elke gelowige het gawes van die Heilige Gees ontvang om deel te neem aan die opbou van die gemeente.

Om hierdie bestaansrede en bedieningsfilosofie te kan uitleef word ' $n$ sewepuntstrategie gevolg:

1. Dit is absoluut noodsaaklik om brûe te bou na buitekerklikes deur gelowiges wat verhoudings (van integriteit en vriendskap) met buitekerklikes aangaan. Pertinente toerusting word daarvoor gegee.

2. ' $n$ Mondelinge getuienis moet eers gedeel word wanneer 'n vertrouensverhouding ontstaan het.

3. Spesiale byeenkomste met 'n byderwetse styl en waarin van modeme kommunikasiehulpmiddels gebruik gemaak word, word gereeld gehou. Hierdie byeenkomste is gerig op belangstellende interkerklike besoekers en die kern van die evangelie word op hedendaagse aktuele vraagstukke toegepas.

4. Nadat iemand klaarblyklik tot bekering gekom het, word hy saamgenooi na die gemeente se eredienste wat new community services genoem word.

5. Elke nuwe gelowige moet inskakel by die samekomste van 'n kleingroep, (growgroups) wat oor 'n periode van twee jaar 'n spesifieke leerplan deurwerk. 
6. Elke nuwe gelowige kry geleentheid om deel te neem aan 'n network seminar waar hy/sy gehelp word om sy eie gawes te identifiseer en by een of ander dienswerk van die gemeente in te skakel.

7. Nadat iemand ingeskakel is as lidmaat word hy/sy gelei om Bybelse insigte oor rentmeesterskap uit te leef en om volgens vermoë ruim by te dra tot die finansiële behoeftes van die gemeente.

\subsubsection{Evaluering}

Die New Life Presbyterian Church is ' $n$ kerk wat op ' $n$ verbeeldingryke manier voluit missionêre gemeente van Christus wil wees. Daar word moeite gedoen om relevant te wees en buitekerklikes werklik in die taal en idioom van hulle eie moderne leefwêreld te bereik. Die entoesiasme wat uit lidmate se deelname spreek, is verbasend. Die groot getalle mense wat na samekomste stroom (sodat selfs die stad se verkeerspolisie die strome verkeer in die straat buite die terrein elke Saterdagaand moet beheer), is verstommend.

Die ampstruktuur val vreemd op die oor, want benewens die ouderlinge is daar ook nog 'n board of directors.

Die motivering vir die noodsaaklikheid van afsonderlike seeker samekomste naas die gewone eredienste is ook nie oortuigend nie. In die lig van Bybelse beginsels (vgl. pt. 2.2 en 2.5) behoort eredienste van so 'n aard te wees dat sowel die ekstensiewe as die intensiewe groei daar kan plaasvind. (Trouens, dit is jammer dat die Bybelse fundering by al die punte van die gemeente se bedieningsfilosofie en ook in die aanbieding van die leadership seminar wat een van die skrywers bygewoon het, uiters skraal is.)

'n Vraag wat deurentyd by ' $n$ mens opkom wanneer hierdie gemeente besoek word en sy bedieningstyl en doelwitte bestudeer word, is of al die moeite om 'relevant' te wees, nie die grens van kompromieë maak oorsteek nie, sodat die evangelie self sy struikelblokkarakter vir die ongelowige verloor nie (1 Pet. 2:5). In hoeverre is pragmatiese oorwegings - meer as prinsipieel Bybelse oorwegings - deurslaggewend in die vormgewing van die bedieningstruktuur in 'n gemeente?

\section{Konklusies}

In al die aspekte van die funksionering van die gemeente, naamlik prediking, onderrig, pastoraat, aanbidding in die gesamentlike erediens, en die opsig en bestuur en leiding van die voorgangers, moet daar 'n integrale eenheid gehandhaaf word tussen die kwalitatiewe en kwantitatiewe opbou en groei en die bewaring en vermeerdering van die kerk. Om te kan bewaar, moet die kerk blywend op vermeerdering gerig wees. Om te kan vermeerder, moet die kerk in 'n hegte liefdesverhouding tot God en tot mekaar bewaar word. Hierdie beginsel is 
nie net bevestig deur die bestudering van die modelle wat hierbo beskryf is nie, maar word ook deur teoloë in Duitsland wat die sekularisasieproses as uitdaging vir die kerk aanvaar, sterk onder die aandag gebring. So byvoorbeeld beweer Christian Schwarz (1992:20) van die "Gemeinde Institut" in Hamburg in 'n verslag - nadat etlike honderde gemeentes in Duitsland, Oostenryk en Switserland ontleed is - dat daar agt basiese beginsels is wat grondliggend is aan alle gebalanseerde groei in die kerk van Christus, naamlik: 'n doelgerigte pastor, medewerkers volgens gawes gestruktureer, Godsvrug wat die hele lewe beheers (Leidenschafiliche Spiritualität), doelmatige strukture, inspirerende eredienste (Inspirerender Gottesdienst), algehele betrokkenheid by kleingroepe, relevante evangelisasie en daadwerklike liefde. Sy finale bevinding was:

In fast allen Gemeinden, die zahlenmäsig wuchsen, waren auch die acht Basisprinzipen relativ stark entwickelt - wohingegen die Gemeinden, die . zahlenmäsig schrumpften, sich auch im blick auf die acht Basisprinzipen schwer taten (Schwarz, 1992:20).

Slegs waar die gemeente voluit leef as liggaam van Christus en werklik deur sy liefde gedring word om in 'n gebroke wêreld kanale van sy liefde teenoor alle mense te wees sal die kerk aanhou om getalsmatig effektief te groei.

Groei kan inderdaad die beste gerealiseer word waar daar sterk klem is op kleingroepbediening, sowel as op feestelike aanbidding in groter samekomste soos die normale eredienste. Selfs in gevestigde kerke wat oneffektief geword het, word kleingroepbediening ervaar as middel tot herstel. Nadat Ortwin Schweitzer bewus geword het van byna 30000 evangeliese Christene wat die afgelope 10 jaar - mede as vrug van sy werk by die "Ambt für missionarische Dienst" betrokke geraak het, kan hy verklaar (Schweitzer, 1992:6):

Es wird das Licht intensiver, so wie auch die Dunkelheit zunimmt. In diesem Rahmen: Laszt uns Gruppen und Zellen aufbauen, laszt uns Hauskreiss Arbeit tun. Wir stehen in einer kirchengeschichllichen wichtigen Situation. Laszt uns bewuszt erkennen, durchleben und nutzen. Heilsgeschichte ist nicht nur Vergangenheil, sie geschicht heute unter uns. Wer Augen hat zu sehen, der sehe! (Beklemtoning deur Schweitzer.)

Dit is egter ook duidelik dat groeiende gemeentes 'n duidelike visie vir kwalitatiewe sowel as kwantitatiewe groeı moet hé wat in alle gestaltes van die bediening in die gemeente na vore kom. Is die probleem dalk dat so 'n duidelike visie by vele refonmatoriese kerke in Suid-Afrika ontbreek?

\section{Bibliografie}

ADAMS, J. E. 1982. Preaching with Purpose Grand Rapids : Baker

ARN, W. 1993. Kennzeichen eines "integrierten" Gemeindeglieds und die 10 grossten Hindernisse Kirchen fur Morgen, 92(1):24 
BANKS, R. 1980. Paul's Idea of Community ; The Early House Churches in Their Historical Setting. Exeter : Paternoster.

BIEDER, W 1964. Das Mysterium Christi und die Mission: ein Beitrag zur missionarischen Sakramentsgestalt der Kirche. Zurich : EVZ Verlag.

BOLKESTEIN, HM 1964. Zielzorg in het Nieuwe Testament. Den Haag : Van Keulen

BOUW, W.J. 1982. Evangelizatie in de tachtiger jaren; het Pattaya-beraad over wereldevangelizatie en de betekenis daarvan voor Nederland. Amersfoort : Echo.

BUYS, P.J. 1989. Die verhouding tussen gemeenteopbou en evangelisering, 'n eksegetiese ondersoek na die betekenis van tersaaklike woorde in die Nuwe Testament en die implikasies daarvan vir die verhouding tussen die bewaring en die vermeerdering van die kerk Potchefstroom : PU vir CHO. (Th.D. proefskrif.)

CHRISTIAN REFORMED HOME MISSIONS. 1984. Evangelism and Worship. Grand Rapids : Christian Reformed Home Missions.

DE RIDDER, R.R. 1971. The Dispersion of the People of God; the Covenant Basis of Matthew 28:18-20 against the Background of Jewish, Pre-Christian Proselyting and Diaspora, and the Apostleship of Jesus Christ. Kampen : Kok

DIJK, K. 1955. De dienst der prediking. Kampen : Kok

DODD, C.H. 1970. (4e dr) The Apostolic Preaching and Its Developments. London : Hodder \& Stoughton.

DOUGLAS, J.D. ed. 1975. Let the Earth Hear His Voice; International Congress on World Evangelism. Minneapolis : World Wide Publications.

ECKERT, J. 1979. The Realisation of Fellowship in the Earliest Christian Communities Concilium, 126-130.

FIRET, J 1968. Het agogisch moment in het pastoraal optreden. Kampen : Kok

GREEN, M. 1979. Evangelism - Now and Then Leicester Intervarsity Press

HART, D.J. 1986. Prediking en evangelisasie. (In Van der Walt, B J red. Sodat my huis vol kan word. Reformatoriese perspektiewe op ons evangelisasieroeping vandag Potchefstroom : PU vir CHO p 64-76.)

KELLER, K. 1992. The God of Great Surprises at Work in New York City: Alumni in Ministry. WTS Bulletin, 30: 4:1-3.

KROL, B. 1993. Kerkelijke ontwikkelingen in Nederland Bulletin voor Gemeentegroei, 3:2, Junie.

MILLER, C.J. 1980. Evangelism and Your Church. Phillipsburg : Presbyterian and Reformed Publ. Co

MOUNCE, R.H. 1960. The Essential Nature of New Testament Preaching Grand Rapids Eerdmans

NEL, M. 1987. Gemeentebediening en evangelisasieperspektief. Skrif en Kerk, 18 (1):52-61.

NEW LIFE PRESBYTERIAN CHURCH. 1992. New Life for Today Philadelphia. (Ongepubliseerde kommissierapport van die kerkraad ) 03/12/92.

NEW LIFE PRESBYTERIAN CHURCH. 1993. Big Picture Thinking Philadelphia: 03/09/93.

PAUW, C.M. 1987. Wat is sending? Riglyne en perspektiewe met die oog op die praktyk Ned. Geref. Teologiese Tydskrif, 27 (1): 28-35.

PETERS, G.W. 1975. Contemporary Practices of Evangelism. (In Douglas, J.D e.a. Let the Earth Hear His Voice. Minneapolis : World Wide Publications. p. 571-583.)

R.E.S. 1987. Mission Bulletin, vii: 3, Sept.

REDEEMER PRESBYTERIAN CHURCH 1993. Introduction to Redeemer (Membership Seminar). New York.

ROBERTS, J.H. 1976. Can Church Offices be Found in Paul? Neotestamentica, 10:1-19

ROBERTS, J.H. 1983 Die brief aan die Efesiërs. Kaapstad : NG Kerkuitgewers.

SCHWARZ, C.H. 1992. Grundkurz Gemeinde. Kirchen für Morgen, 92(1):11. 
SCHWEITZER, O. 1992. Geschichtliche Grundlagen der Hauskreisarbeit. Stuttgart Amt für missionarische Dienste

SNYMAN, W J. 1967. Openbaringsgeskiedenis Nuwe Testament. Die vier evangelies. Potchefstroom : Pro Rege.

STEWART, B. 1991. Willow Creek Community Church; Church Leaders Handbook. South Barrington : Willow Creek Community Church.

TE VELDE, M 1992. Gemeenteopbouw 2, Bijbelse basisprincipes voor het functioneren van de christelijke gemeente. Barneveld : Vuurbaak.

TOWNS, E.M 1990. An Inside Look at 10 of Today's Most Innovative Churches, What They're Doing. How They're Doing It \& How You Can Apply Their Ideas in Your Church Ventura : Regal Books

VAN EEDEN, I.J. 1986. Kerkspieel 2. Pretoria : NG Kerkboekhandel.

VAN SWIGCHEM, D 1955. Het missionair karakter van de christelijke gemeente volgens de brieven van Paulus en Petrus. Kampen : Kok.

VERSTEEG, J.P. 1985. Kijk op de kerk; De struktuur van de gemeente volgens het Nieuwe Testament Kampen : Kok.

VOGLER, W. 1982 Die Bedeutung der urchristlichen Hausgemeinden für die Ausbreitung des Evangeliums. Theologische Literaturzeitumg. 107 (11):785-794.

VON ALLMEN, J.J. 1965 Worship: Its Theology and Practice. London : Lutterworth

WATSON, D 1978. I Believe in the Church London: Hodder and Stoughton. 
